\title{
EVALUATION OF THYROID FUNCTION TEST IN OBESE PATIENTS
}

\author{
FAAZILA FATHIMA ${ }^{1 *}$, PREETHA ${ }^{2}$
}

${ }^{1}$ Saveetha Dental College and Hospitals, Saveetha University, Chennai, Tamil Nadu, India. ${ }^{2}$ Department of Physiology, Saveetha Dental College and Hospitals, Saveetha University, Chennai, Tamil Nadu, India. Email: faazilafathima5@gmail.com

Received: 20 May 2016, Revised and Accepted: 02 August 2016

\section{ABSTRACT}

Objective: To evaluate thyroid function in 20-50 aged obese people. As obesity is a widespread problem today, knowledge about the factors affecting or influencing it is important. Little is known about the changes in thyroid function obese people. Influence on thyroid hormone synthesis has been proposed.

Methods: Thyroid function test was done for 30 obese and 30 nonobese people, and their thyroid-stimulating hormone (TSH) levels were compared.

Results: Using paired $t$-test, we found that there is a statistically significant difference between TSH levels in obese and nonobese people at $\mathrm{p}<0.001$.

Keywords: Thyroid, Obese, Nonobese, Thyroid function test.

(C) 2016 The Authors. Published by Innovare Academic Sciences Pvt Ltd. This is an open access article under the CC BY license (http://creativecommons. org/licenses/by/4. 0/) DOI: http://dx.doi.org/10.22159/ajpcr.2016.v9s3.12959

\section{INTRODUCTION}

Obesity is a leading preventable cause of death worldwide, with increasing rates in adults and children. It is a condition in which excess body fat has accumulated to the extent that it may have a negative effect on health leading to a reduced life expectancy and increased health problems. Body mass index (BMI) is a very relevant parameter to decide if a person is obese. The BMI is defined as the body mass divided by the square of the body height. In some countries, people are considered obese when the BMI exceeds $30 \mathrm{~kg} / \mathrm{m}^{2}$. A BMI of $<18.5$ is considered underweight while $\mathrm{BMI} \geq 30$ is considered obese as established by WHO [1]. Some studies show that there is a relation between small size at birth and obesity, and this may contribute to the pathogens underlying the fetal origins hypothesis [2]. In recent studies, people who were thin at birth and then showed rapid childhood growth had the greatest risk for diseases in adulthood [3,4]. The etiology or cause of obesity is an imbalance between the energy ingested in food and the energy expended [5].

As obesity is a widespread problem today, knowledge about the factors affecting or influencing it is important. Little is known about the changes in thyroid function in obese people. Influence on thyroid hormone synthesis has been proposed. Thyroid function has been often described as altered in obese children; however, it is not clear whether the altered thyroid function is the cause or the consequence of fat excess [6].

Long before the definition of the metabolic syndrome, alterations in thyroid function were reported in obese patients. Body composition and thyroid hormones appear to be closely related since the latter is known to be involved in the regulation of basal metabolism and thermogenesis, playing an important role in lipid and glucose metabolism, food intake, and fat oxidation $[7,8]$. An important cause of obesity is said to be hormonal imbalance as in hypothyroidism (underactive thyroid gland). Since obesity is related to hormonal imbalance, in this study, the levels of thyroid hormones in obese patients have been studied to find out the relation between them both.

Thyroid is a large ductless gland in the neck which secretes hormones regulating growth and development through rate of metabolism. Thyroid hormones play critical roles in differentiation, growth, and metabolism. Thyroid hormone is required for normal function of nearly all tissues, with major effects on oxygen consumption and metabolic rate. The thyroid hormone binds on to the receptor that is ligandregulatable transcription factors. Thyroid hormone synthesis and secretion is exquisitely regulated by a negative-feedback system that involves the hypothalamus, pituitary, and the thyroid gland. Thyroidstimulating hormone (TSH) is the primary regulator of thyroid hormone. Thyroid hormone has many effects on the heart and vascular system. Many of the clinical manifestations of hyperthyroidism are due to the inability of thyroid hormone to alter cardiovascular hemodynamics [9]. In rat brain, the levels if thyroid receptor-B messenger RNA increased 40 -folds from 19 days of gestation to 10 days after birth, a period that coincides with T3-regulated developmental changes in the brain [10]. The thyroid hormone-induced increase in thermogenesis is explained, among other things, by an increased need for adenosine triphosphate (ATP) due to increased activity in most cells and reduced efficiency of ATP synthesis [11]. Disorders of the thyroid gland are among the most common endocrine problems [12]. Thyroid hormone status affects the functioning renal mass (measured as the kidney to body mass ratio), with hypothyroidism reducing this ratio and hyperthyroidism increasing it [13]. During the process of development, apoptosis and cellular proliferation are balanced by this multihormonal mechanism, the major actor of which is triiodothyronine (T3) [14]. Some studies show that triiodothyronine controls metabolic and energy homeostasis, and this influences body weight and TSH via receptors in fat tissues inducing differentiation of preadipocytes to adipocytes and expansion of adipose tissue [15]. The thyroid hormone, thyroxine promotes protein synthesis and growth and also helps to regulate the body's metabolism. Thyroxine forms by combining the amino acid tyrosine with iodine. Some common thyroid disorders include Graves' disease, goiter, Hashimoto's disease, and thyroid nodules. Most of these occur due to problems in the thyroid gland. It is necessary to prevent the factors influencing these disorders as thyroid hormones regulate a lot of functions in our body. Thus, information about thyroid gland and its hormones is of at most importance.

In this study, we aim to find out the relation between obesity and thyroid. For this, a thyroid function test is done. It is a collective term for blood test used to check the function of thyroid [16]. A thyroid function test panel includes thyroid hormones such as TSH, thyroxine, and triiodothyronine (T3). Studies on thyroid hormone in obese adults are inconsistent [17]. Long-term changes in thyroid hormones caused by a reduction in weight have not been studied in depth [18]. Thus, in this study, we aim to find out the relation between obesity and thyroid. 
For this, a thyroid function test is done. It is a collective term for blood test used to check the function of thyroid [16].

\section{METHODS}

The reports of thyroid levels of 60 patients were collected from a private clinic, Chennai.

For this study, 30 obese and 30 nonobese people were chosen falling between the age group of 20-50 years. The patients whose BMI was 25 and above was considered obese and those, whose BMI was $<25$, was taken into the nonobese category. A thyroid function test was done, and the TSH levels were recorded in obese and nonobese people.

\section{RESULTS}

Using paired t-test, we found that there is a statistically significant difference between TSH levels in obese and nonobese people at $\mathrm{p}<0.001$.

\section{DISCUSSION}

From this study, it is clear that there is a highly significant relationship $(\mathrm{p}<0.00)$ between TSH levels and BMI (Fig. 1 and Table 1). It was found when the BMI levels where 30 or more the TSH levels were significantly high on comparison with the TSH level in patients with BMI $<18.55$ (Table 2). Obesity leads to multiple metabolic disorders that increase the mortality and morbidity risk in adulthood [19-21]. Since obesity is of great concern in today's world, it is very necessary to know about the factors affecting obesity. In a study done by Silvia Longhi and Giorgio Radetti, it was described that thyroid test was often being altered in obese children but was unclear if it was the cause or the consequence of fat excess [22]. Body composition and thyroid hormones appear to be closely related since the latter is known to be involved in the regulation

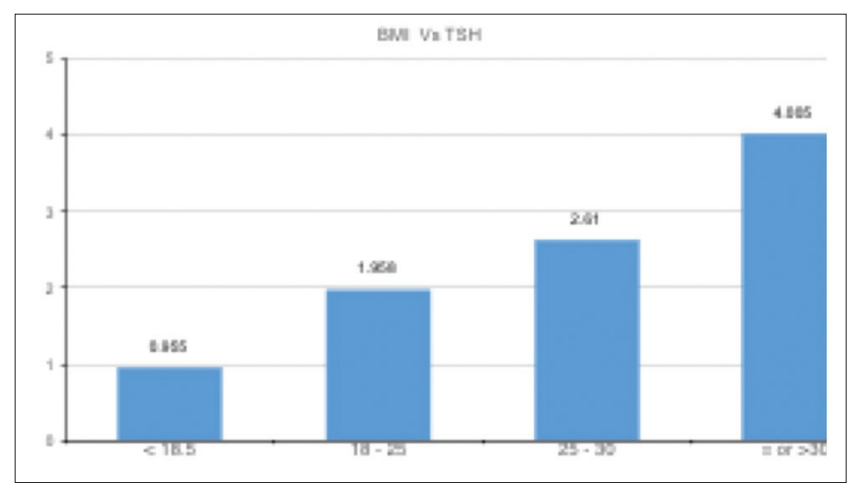

Fig. 1: This graph depicts the relation between body mass index and thyroid-stimulating hormone

Table 1: It shows the mean, standard deviation, and $p$ value of obese and nonobese group

\begin{tabular}{llll}
\hline Group & Mean & Standard deviation & $\mathbf{p}$ \\
\hline Obese & 4.00673 & 2.169642 & 0.00 \\
Nonobese & 2.25033 & 1.309327 & 0.00 \\
\hline
\end{tabular}

Table 2: It shows the BMI description and respective average TSH

\begin{tabular}{lllll}
\hline BMI & BMI descripton & Number of patients & Sum of TSH uUI/mL & 0.955 \\
\hline$<18.5$ & Under weight & 1 & 27.406 & 0.955 \\
$18-25$ & Normal weight & 14 & 39.149 & 1.958 \\
$25-30$ & Over weight & 15 & 120.142 & 2.61 \\
$\geq 30$ & Obese & 30 & & 4.005 \\
Total & & 60 &
\end{tabular}

BMI: Body mass index, TSH: Thyroid-stimulating hormone of basal metabolism and thermogenesis, playing an important role in lipid and glucose metabolism, food intake, and fat oxidation [18,12]. Some studies have also reported that there is an inverse correlation between free thyroxine (fT4) values and BMI, even when fT4 values remain in the normal range [23]. In various studies on adult obese individuals, thyroid hormone and TSH concentrations have been described as normal, elevated, or reduced, compared to a control group [18,24-29]. In a study carried on by Strata et al., it appeared that thyroid function was normal in obesity [30]. A relationship has been found between body weight and thyroid disease; the study was, however, based on self-reported thyroid dysfunction, and data were from a highly selected cohort of weight-conscious women [31]. While in another study, which included 85-year-old subjects, an association was found between thyroid function and BMI [32]. In a cross-sectional study carried on, it was found a higher BMI among women with subclinical hypothyroidism of borderline statistical significance, but the opposite association was found among men [33]. While in a study carried on by Krotkiewski, the results showed an established association between overt thyroid dysfunction and weight changes because weight loss is a relatively constant phenomenon in hyperthyroidism [34]. Similarly, a positive association between BMI and category of serum TSH $(p=0.001)$ was observed in the study done by Nils et al. [35]. In the study done by Reinche and Andler, it was reported that obese children had serum concentrations of thyroid hormones (TSH, T3, T4) on average above those of the children of normal weight [23]. A moderate rise in total TSH concentrations of obese children has also been shown in a number of other studies [36-39]. The cause of the increased thyroid hormone concentrations in obesity is unclear [23]. Increased thyroid hormone concentrations could point to hormone resistance, similar to insulin resistance in obesity [36]. In support of this theory is the fact that in obesity, T3 receptors are decreased [40], and the negative feedback between TSH and the peripheral thyroid hormones (T3, T4) is decreased, as both TSH and the peripheral thyroid hormones are increased in obesity [23]. As the thyroid hormones, especially $\mathrm{T} 3$, regulate both the resting metabolic rate and thermogenesis and lead to lipolysis $[36,41,42]$. Changes in thyroid hormones could also point to an adaptation process in obesity [23]. Production of TSH is also regulated by transmitters and hormones which regulate body weight and satiation, such as neuropeptide $\mathrm{Y}, \alpha$ melanocytestimulating hormone, and the agouti-related peptide innervating hypophysiotropic TRH neurons [43]. Variations in thyroid function are seen between individuals also within the normal range, documented by relatively small individual variation in serum levels of thyroid hormones and TSH between measurements in the same individual compared with variations between individuals [44]. Such differences in individual thyroid function are caused by a combination of genetic and environmental factors [45]. Calorie reduction, increased physical activity, and behavior therapy are recommended as the first line treatment for obesity with consideration of pharmacological therapies as a secondary alternative [46]. In summary, an increased TSH level in found in obese patients. There is no necessity for treatment of the increased thyroid hormones. A normal energy diet induces a long-term decrease in the peripheral thyroid hormones as opposed to TSH [23].

\section{CONCLUSION} between BMI and thyroid levels. From the results, it was clear that BMI and TSH are proportional that is more the BMI, more is the thyroid level.
This study concludes that there is a highly significant relationship

$\mathrm{p}<0.00$ 


\section{REFERENCES}

1. BMI Classification. Global Database on Body Mass Index. Geneva: World Health Organization; 2006. ???. [Last retrieved on 2012 Jul 27].

2. Ong KK, Ahmed ML, Emmett PM, Preece MA, Dunger DB Association between postnatal catch up growth and obesity in childhood: Prospective cohort study. BMJ 2000;320(7240):967-71.

3. Eriksson JG, Forsén T, Tuomilehto J, Winter PD, Osmond C, Barker DJ. Catch-up growth in childhood and death from coronary heart disease: longitudinal study. BMJ 1999 13;318(7181):427-31.

4. Crowther NJ, Cameron N, Trusler J, Gray IP. Association between poor glucose tolerance and rapid post natal weight gain in seven-year-old children. Diabetologia 1998;41:1163-7.

5. Reinehr T, Andler W. Thyroid hormones before and after weight loss in obesity. Arch Dis Child 2002;87(4):320-3

6. Rotondi M, Leporati P, La Manna A, Pirali B, Mondello T, Fonte R, et al. Raised serum TSH levels in patients with morbid obesity: Is it enough to diagnose subclinical hypothyroidism? Eur J Endocrinol 2009;160(3):403-8

7. Silva JE. Thermogenic mechanisms and their hormonal regulation. Physiol Rev 2006;86(2):435-64

8. Rosenbaum M, Hirsch J, Murphy E, Leibel RL. Effects of changes in body weight on carbohydrate metabolism, catecholamine excretion, and thyroid function. Am J Clin Nutr 2000;71(6):1421-32.

9. Klein I, Ojamaa K. Thyroid hormone and the cardiovascular system. N Engl J Med 2001;344(7):501-9.

10. Strait KA, Schwartz HL, Perez-Castilleo A, Oppenheiner JH Relationship of C-erb AMRNA context to tissue triiodothyroxine nuclear binding capacity and function in developing and adult rats. J Biol Chem 1990;265:10514-21.

11. Sestoft L. Metabolic aspects of the calorigenic effect of thyroid hormone in mammals. Clin Endocrinol (Oxf) 1980;13(5):489-506.

12. Yen PM. Physiological and molecular basis of thyroid hormone action. Physiol Rev 2001;81(3):1097-142.

13. Vargas F, Moreno JM, Rodriguez-Gomez I, Wangensteen R, Osuna A, Alvarez-Guerra $\mathrm{M}$, et al. Vascular and renal function in experimental thyroid disorders. Eur J Endocrinol. 2006;154(2):197-212.

14. Tata JR. Amphibian metamorphosis as a model for the developmental actions of thyroid hormones. Mol Cell Endocrinol 2006;246(1-2):10-20.

15. Bandurskha-Stanbusviez E. Thyroid hormone- obesity and metabolic syndrome. Thyroid Research 2013;6(Suppl 2):A5.

16. Dayan CM. Interpretation of thyroid function tests. Lance 2001;357(9256):619-24.

17. Rosenbaum M, Vandenborne K, Goldsmith R, Simoneau JA, Heymsfield S, Joanisse DR, et al. Effects of experimental weight perturbation on skeletal muscle work efficiency in human subjects. Am J Physiol Regul Integr Comp Physiol 2003;285(1):R183-92.

18. Tagliaferri M, Berselli ME, Calò G, Minocci A, Savia G, Petroni ML, et al. Subclinical hypothyroidism in obese patients: Relation to resting energy expenditure, serum leptin, body composition and lipid profile. Obes Res 2001;9(3):196-201.

19. Daniels SR. The consequences of childhood overweight and obesity. Future Child 2006;16(1):47-67.

20. Weiss R, Dziura J, Burgert TS, Tamborlane WV, Taksali SE, Yeckel CW, et al. Obesity and the metabolic syndrome in children and adolescents. N Engl J Med 2004;350(23):2362-74.

21. Pearce EN. Thyroid hormone and obesity. Curr Opin Endocrinol Diabetes Obes 2012;19(5):408-13.

22. Longhi S, Radetti G. Thyroid function and obesity. J Clin Res Pediatr Endocrinol 2013;5 Suppl 1:40-4.

23. Knudsen N, Laurberg P, Rasmussen LB, Bülow I, Perrild H, Ovesen L, et al. Small differences in thyroid function may be important for body mass index and the occurrence of obesity in the population. J Clin Endocrinol Metab 2005;90(7):4019-24.

24. Reinehr T, de Sousa G, Andler W. Hyperthyrotropinemia in obese children is reversible after weight loss and is not related to lipids. J Clin Endocrinol Metab 2006;91(8):3088-91.

25. Chomard P, Vernhes G, Autissier N, Debry G. Serum concentrations of total $\mathrm{T} 4, \mathrm{~T} 3$, reverse $\mathrm{T} 3$ and free $\mathrm{T} 4, \mathrm{~T} 3$ in moderately obese patients.
Hum Nutr Clin Nutr 1985;39(5):371-8.

26. Matzen LE, Kvetny J, Pedersen KK. TSH, thyroid hormones and nuclear-binding of T3 in mononuclear blood cells from obese and nonobese women. Scand J Clin Lab Invest 1989;49(3):249-53.

27. Duntas L, Hauner H, Rosenthal J, Pfeiffer EF. Thyrotropin releasing hormone (TRH) immunoreactivity and thyroid function in obesity. Int J Obes 1991;15(1):83-7.

28. Näslund E, Andersson I, Degerblad M, Kogner P, Kral JG, Rössner S, et al. Associations of leptin, insulin resistance and thyroid function with long-term weight loss in dieting obese men. J Intern Med 2000;248(4):299-308.

29. Iacobellis G, Ribaudo MC, Zappaterreno A, Iannucci CV, Leonetti F. Relationship of thyroid function with body mass index, leptin, insulin sensitivity and adiponectin in euthyroid obese women. Clin Endocrinol (Oxf) 2005;62(4):487-91.

30. Strata A, Ugolotti G, Contini C, Magnati G, Pugnoli C, Tirelli F, et al. Thyroid and obesity: survey of some function tests in a large obese population. Int J Obes 1978;2(3):333-40.

31. Rimm AA, Werner LH, Yserloo BV, Bernstein RA. Relationship of obesity and disease in 73,532 weight-conscious women. Public Health Rep 1975;90(1):44-54.

32. Gussekloo J, van Exel E, de Craen AJ, Meinders AE, Frolich M, Westendorp RG. Thyroid status, disability and cognitive function, and survival in old age. JAMA 2004;292(21):2591-9.

33. Lindeman RD, Romero LJ, Schade DS, Wayne S, Baumgartner RN, Garry PJ. Impact of subclinical hypothyroidism on serum total homocysteine concentrations, the prevalence of coronary heart disease (CHD), and CHD risk factors in the New Mexico elder health survey. Thyroid 2003;13:595-600.

34. Krotkiewski M. Thyroid hormones in the pathogenesis and treatment of obesity. Eur J Pharmacol 2002;440:85-98.

35. Srinivasan SR, Myers L, Berenson GS. Temporal association between obesity and hyperinsulinemia in children, adolescents, and young adults: The Bogalusa Heart Study. Metabolism 1999;48(7):928-34.

36. Kiortis DN, Durack I, Turpin G. Effects of a low-calorie diet on resting metabolic rate and serum tri-iodothyronine levels in obese children. Eur J Pediatr 1999;158(6):446-50.

37. Stichel H1, l'Allemand D, Grüters A. Thyroid function and obesity in children and adolescents. Horm Res 2000;54(1):14-9.

38. Bray GA, Chopra IJ, Fischer DA. Relation of thyroid hormones to body-weight. Lancet 1976;I:1206-8

39. Maccario M, Oleandri SE, Valetto MR, Savio P, Aimaretti G, Baffoni C, et al. Pituitary-thyroid axis in obesity. Int J Obes 1998;22:175.

40. Burman KD, Latham KR, Djuh YY, Smallridge RC, Tseng YC, Lukes YG, et al. Solubilized nuclear thyroid hormone receptors in circulating human mononuclear cells. J Clin Endocrinol Metab 1980;51(1):106-16.

41. Ravussin E, Burnard B, Schutz Y, Jéquier E. Twenty-four-hour energy expenditure and resting metabolic rate in obese, moderately obese, and control subjects. Am J Clin Nutr 1982;35(3):566-73.

42. Toubro S, Sorensen TIA, Ronn B, Christensen NJ, Astrup A. Twentyfour-hour energy expenditure: The role of body composition, thyroid status, sympathetic activity and family membership. J Clin Endocrinol Metab 1996;81(7):2670-4.

43. Zwiauer KF, Mueller T, Widhalm K. Resting metabolic rate in obese children before, during and after weight loss. Int J Obes 1992;16(1):11-6.

44. Hansen PS, Brix TH, Sorensen TI, Kyvik KO, Hegedus L. Major genetic influence on the regulation of the pituitary-thyroid axis: A study of healthy Danish twins. J Clin Endocrinol Metab 2004;89(3):1181-7.

45. Andersen S, Pedersen KM, Bruun NH, Laurberg P. Narrow individual variations in serum $\mathrm{T}(4)$ and $\mathrm{T}(3)$ in normal subjects: A clue to the understanding of subclinical thyroid disease. J Clin Endocrinol Metab 2002;87(3):1068-72.

46. Connolly J, Romano T, Patruno M. Selections from current liberation: Effects of dieting and exercise on resting metabolic rate and implications for weight management. Fam Pract 1999;16(2):196-201. 